\title{
Green Supply Chain Management (GSCM) Practices for Sustainability Performance: An Empirical Evidence of Malaysian SMEs
}

\author{
Zarinah Abdul Rasit ${ }^{1}$, Maisurah Zakaria ${ }^{1}$, Marshita Hashim ${ }^{1}$, Aliza Ramli $^{1} \&$ Muzrifah Mohamed ${ }^{1}$ \\ ${ }^{1}$ Faculty of Accountancy, UiTM Selangor, Bandar Puncak Alam, Malaysia \\ Correspondence: Zarinah Abdul Rasit, Faculty of Accountancy, UiTM Selangor, Bandar Puncak Alam, Malaysia.
}

Received: April 20, 2019

Accepted: May 7, 2019

Online Published: May 19, 2019

doi:10.5430/ijfr.v10n3p371

URL: https://doi.org/10.5430/ijfr.v10n3p371

\begin{abstract}
Environmental issues have been critical concern among the current businesses as various business activities might pose significant threats to the environment. Incorporating environmental aspects in business operations is perceived to be able to create value and to achieve sustainable business performance. The manufacturing sector is the key contributor to the country's high pollution index. Green Supply Chain Management (GSCM) practices have become more prevalent in this sector in managing the environmental issues for the effectiveness of their production requirement. Nevertheless, the small and medium enterprises (SMEs) mainly are less likely to embark on environmental practices as compared to large organisations. The establishment of certified environmental management systems (EMS) is considered as a strategic management approach that defines how organisations will address their impact on the natural environment guided by ISO 14001 as a framework. This study provides empirical evidence examining the extent of GSCM practices among the SMEs through the possession of ISO 14001 and examines the impact on sustainability performance. Data were analysed using regression analyses. Results indicate that GSCM practices have a significant positive relation with sustainability performance. Eco-design practices and environmental cooperation have a positive relationship with sustainability performance. There is no relationship between green purchasing and reverse logistics practices with sustainability performance. These results imply that Malaysian SMEs adopt GSCM practices mostly through eco-design and robust cooperation among departments in dealing with environmental issues. Green practices and reverse logistics practices are still new for SMEs and do not contribute to achieving better performance.
\end{abstract}

Keywords: green supply chain management, sustainability performance, SMEs, Environmental Management System (EMS), ISO 14001

\section{Introduction}

Environmental issues have been gaining significant attentions in the current business environment with increasing competition and stakeholders' demands. Most businesses nowadays are concerned about environmental aspects as various business activities might contribute significant threat to the environment. Incorporating environmental aspects in business operation helps companies to create long-term values important for sustainability performance. In Malaysia, the manufacturing sector is the key contributor to the country's pollution index (Hassan, Ashari and Nordin, 2016). As a consequence, GSCM practices have become prevalent in this sector to manage environmental issues for the effectiveness of their productions (Wooi and Zailani, 2010). The Malaysian Economic Transformation Programme (ETP) has also highlighted the green technology development in the effort towards achieving developed-nation status (Yacob, Aziz, Makmor and Zin, 2013).

According to The Star Online (2017), SMEs recorded strong growth and provided a high contribution to the national gross domestic product (GDP). Nevertheless, Yacob et al. (2013) claimed that SMEs are less likely to embark on green practices as compared to large organisations. The establishment of certified environmental management systems (EMS) is considered as a strategic management approach that defines how organisations will address its impact on the natural environment guided by ISO 14001 as a framework (Darnall, Jolley \& Handfield, 2008). GSCM practices are believed to be more efficiently implemented if the organisations hold EMS certification to help in handling environmental issues (Sarkis, 2003). Thus, it is essential to examine the extent of green practices in SMEs and its impacts on performance. This study examines sustainability performance among SMEs in Malaysia's manufacturing sector through the possession of ISO 14001 in GSCM practices. According to Mentzer (2001), a 
network comprises of all parties involved directly or indirectly in the production and delivery process to the final customers constitute a supply chain.

Sizeable prior studies found that GSCM practices positively influence firm performance; environmental, economic, social or operational aspects (Balasubramanian \& Shukla, 2017). Each of this aspect of performance is perceived as essential indicators of sustainability performance for organisations because the business environment nowadays is highly competitive and increasing demand from consumers regarding the environmental concern and the preference of eco-friendly products. Numerous studies have been conducted on large-sized and multinational organisations due to the implementation of green practices like green logistics (Mogeni \& Kiarie, 2016; Artha \& Mulyana 2018), green supplier selection, green purchasing, green production, green design and green distribution (Alshura \& Awawdeh, 2016).

However, the study among SMEs in regards to green practices is still insufficient and needs to be emphasised considering the importance of SMEs towards Malaysia's economy. This study fills the gap by examining the relationships between GSCM practices and sustainability performance focusing on SMEs manufacturing sectors with the ISO 14001 certification. Findings from the research will contribute to the literature on GSCM and its implementation in SMEs. The research will provide further insight into the importance of EMS and the ISO 14001 in GSCM implementation that may lead to enhance sustainability performance.

\section{Literature Review and Hypotheses Development}

\subsection{Green Supply Chain Management (GSCM) and Sustainability Performance}

The supply chain management (SCM) concept was introduced in 1990 which involves inventory management, the relationship between customer and supplier, product delivery and all activities associated with the flow of goods starting from raw materials to the final users (Mentzer, 2001). Due to the increasing environmental awareness, GSCM was introduced and acted as a revolution in this current era (Schaper, 2002; ARUNA, 2018). Previous studies found that the adoption of certified EMS by ISO 14001 would lead to a better environmental performance in an organisation (Darnall et al., 2008; Chin et al., 2015; Vijayvargy, 2017). Adopters of EMS may have greater ease during GSCM implementation since they possess the required knowledge and skills to manage the environmental impacts on their supply chain and consequently improve the overall performance of the organisation (Darnall et al., 2008). Organisation that adopt GSCM practices may eventually boost both their competitiveness and economic performance (Rao \& Holt, 2005) as the outcomes of ISO 14001 and GSCM practices are positively related to performance (Vijayvargy, 2017). Based on findings from previous literature, research suggests the following hypothesis:

H1: There is a positive relationship between GSCM practices and sustainability performance.

\subsubsection{Eco-design and Sustainability Performance}

Eco-design is known as the green design that can minimise negative impacts throughout the production process ( $\mathrm{Al}$ Khattab, Abu Rumman \& Massad, 2015; Alshura \& Awawdeh, 2016). Eco-design practices such as product design comprises parameters such as ideal consumption of material or energy, minimisation or avoidance of usage of hazardous materials in product development and reduction of wastes (Sharma \& Jain, 2017; Asif,et.al 2018). These practices involve efficient usage of friendly energy sources such as solar energy and biodegradable energy sources during the manufacturing which aims to reduce the environmental impact and consequently increase the productivity (Amemba, Nyaboke, Osoro \& Mburu, 2013). These practices involve efficient usage of friendly energy sources in manufacturing process which consequently increase the productivity in the organisations (Amemba, Nyaboke, Osoro and Mburu, 2013; Asli, 2018). Zhu et al. (2007) provide evidence that eco-design practices may benefit the organisations to have access in green markets, remanufacturing chances, enhancement in reuse and have a developed eco-efficiency which subsequently will lead the organisations to gain sustainability performance. Thus, the following hypothesis is developed.

H1(a): There is a positive relationship between eco-design practices and sustainability performance.

\subsubsection{Green Purchasing and Sustainability Performance}

Green purchasing is defined as a purchasing method to ensure minimisation of wastes that involves purchasing procedures such as the selection of suppliers, evaluation process, raw materials acquisition, reuse and recycling complied with environmental protection standard (Zsidisin \& Siferd, 2001, Younis et al., 2016). The method is also known to align with an organisation's sustainability performance objective (Lee \& Cheong, 2011; Hassan et al., 2016). Green purchasing practices provide a significant contribution to organisational performance in the long run 
(Nderitu \& Ngugi, 2014) as the purchasing process will ensure all the purchased materials are safe to the purchasing organisations and meet the environmental criteria. Green purchasing practices will build a right "green" image in the market and subsequently could maintain business performance (Zhu et al., 2008; Audu, 2018). This practice involves several initiatives which might be beneficial for organisations' performance. The practices also include developing a cleaner technology to achieve sustainability performance (Muma et al., 2014). This kind of activities is believed to provide an essential contribution to sustainability performance (Nderitu \& Ngugi, 2014). Thus, the following hypothesis is proposed.

H1(b): There is a positive relationship between green purchasing practices and sustainability performance.

\subsubsection{Environmental Cooperation and Sustainability Performance}

The cooperation among all departments must exist in an organisation in dealing with environmental issues (Younis et al., 2016). Top management's commitment plays a critical role in maintaining the sustainability performance through GSCM practices (Chin et al., 2015). Additionally, collaboration with external stakeholders such as suppliers is also crucial in meeting organisational objectives in strengthening environmental awareness (Paulraj, 2011). The integration of suppliers acts as a tool to support environmental cooperation at the strategic, tactical and operational levels (Kim \& Chai, 2017). The cooperation practices act as a collaborative tool to facilitate GSCM practices to be implemented effectively to achieve sustainability performance (Rahim, Fernando \& Saad, 2016). The collaboration is identified as a positive determinant of sustainability performance (Dubey et al., 2014) since environmental sustainability may not be achieved without the cooperation gained from its suppliers. Therefore, it is vital for managers to inspire all parties to get involved in the chain to ensure GSCM practices well adopted to achieve sustainability performance (Neramballi et al., 2017). Consequently, the following hypothesis was developed.

H1(c): There is a positive relationship between environmental cooperation practices and sustainability performance.

\subsubsection{Reverse Logistics and Sustainability Performance}

Reverse logistics relate to activities for further manufacturing or recycling purposes after products receipt. Sub-practices of reverse logistics consist of product return, material reuse, recycling, waste disposal and reproduction (Muma, Nyaoga, Matwere \& Nyambega, 2014). The reverse logistics practices require organisations to recollect used products to reuse recollect used packaging from customers and return products to suppliers for remanufacturing purposes (Sharna \& Jain, 2017; Bachev, 2018). This practice leads to excellent results as reverse logistics are found to be positively related to environmental performance (Muma et al., 2014; Chin et al., 2015). Reverse logistics is part of GSCM innovation and have been proven to serve the green supply chain at the optimum level (Rogers \& Tibben-Lembke, 2001). Sustainability in the supply chain could not be achieved without appropriate management reverse logistics processes as part of green logistics strategy to meet sustainability performance (Chin et al., 2015). Hence, this sub-hypothesis was developed.

$\mathrm{H} 1(\mathrm{~d})$ : There is a positive relationship between reverse logistics practices and sustainability performance.

Figure 1 presents the framework of the study that comprises SCM as the independent variable and sustainability performance as the dependent variable. The framework provides the detail of the relation between the variables. GCSM is measured based on a few green practices that include eco-design, green purchasing, environmental cooperation and reverse logistics. The framework proposes that GCSM contribute towards sustainability performance. Besides, each of the green practices to certain extent also contributes to sustainability performance. As proposed by Madhani (2010), the resource-based theory provides support for the link between resources and capabilities within firms in order to achieve sustainability. ISO 14001 possession is considered as a particular system that is part of firm capabilities that help to enhance sustainability performance (Nee \& Wahid, 2010).

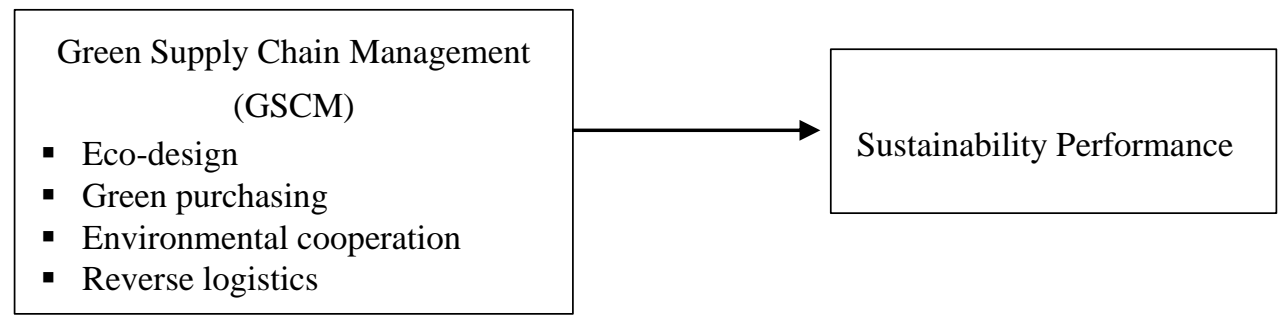

Figure 1. Theoretical framework of the research 


\section{Research Methodology}

\subsection{Sample and Data Collection}

In order to achieve the objectives of this study, a questionnaire survey adapted from Younis et al. (2016) was used as the research instrument for data collection. The unit analysis of this research is firm with ISO 14001 certification. SMEs in the manufacturing sector were selected because they significantly contribute to the Malaysian economy (Kassim \& Sulaiman, 2011). This study used a stratified sampling method whereby the total population is divided into smaller groups which focused on SMEs in the manufacturing sector located in Selangor. It consisted of 92 organisations as listed in the Federation of Malaysian Manufacturing (FMM) Directory 2017 with the size of companies being 200 employees and below. Apart from relying on the number of employees, the organisations' total assets and total revenue were also taken into consideration. In addition to that, the sample was also selected based on the possession of ISO 14001 certification. It is because ISO 14001 certified manufacturing organisations are more likely to be involved in the implementation of GSCM (Arimura, Darnall \& Katayama, 2011). A total of 85 questionnaires were returned and usable from the total sample of 92 SMEs manufacturing organisations located in Selangor giving a response rate of 92.39 per cent.

\subsection{Measurements of Variables}

\subsubsection{Green Supply Chain Management (GSCM)}

In this study, GSCM refers to the extent of green practices being implemented in the supply chain of a firm. The measurement of GSCM is adopted from Younis, Sundarakani and Vel (2016) which includes green purchasing, eco-design, environmental cooperation and reverse logistics. Green purchasing is measured based on four (4) items from Zsidisin and Hendrick (1998). The method is described as purchasing procedure complies with the environmental requirement to minimise cost and to reduce negative environmental impact (Younis et al., 2016; Zsidisin \& Siferd, 2001: Lee \& Cheong, 2011). Eco-design is measured based on four (4) items and is referred to the green design of the product throughout the production process to reduce negative environmental impact and for cost reduction (Alshura \& Awawdeh, 2016). Environmental cooperation refers to the support among all departments including suppliers and with regards to the environmental related matter exists in an organisation to achieve the green objectives (Younis et al., 2016; Paulraj, 2011; Kim \& Chai, 2017). Finally, Reverse logistics is measured by three (3) items, using instruments by Rao (2007) which refers to activities related to further manufacturing or recycling purposes after products receipt.

\subsubsection{Sustainability Performance}

In this study, sustainability performance is measured based a five-point Likert scale on four aspects of performance which include five (5) items measuring environmental performance, six (6) items economic performance, five (5) items social performance and four (4) items operational performance (Younis et al., 2016).

\section{Results and Discussion}

\subsection{Profile of Firms and Respondents}

Table 1 presents a profile of the respondents' firms in this study. Majority of the respondents are food and beverages manufacturer and followed by textiles and apparel products. For the years of operation, the majority have operated more than ten years. Most of the small enterprises have sales less than RM15 million annually, and medium enterprises have sales less than RM 50 million annually. All the respondents are ISO 14001 certified organisations with the majority are more than six years certified by ISO 14001.

Table 1. Profile of the organizations

\begin{tabular}{llll}
\hline Demographic Information & Categories & Frequency & Per cent (\%) \\
\hline Type of products manufactured & Food and beverages & 20 & 23.5 \\
\cline { 2 - 4 } & Furniture & 8 & 9.4 \\
\cline { 2 - 3 } & Textiles and apparel & 17 & 20.0 \\
\cline { 2 - 4 } & Rubber and plastic & 13 & 15.3 \\
\cline { 2 - 3 } & Wood & 5 & 5.9 \\
\cline { 2 - 3 } & Paper & 12 & 14.1 \\
\hline
\end{tabular}




\begin{tabular}{llll}
\hline & Motor vehicles & 6 & 7.1 \\
\cline { 2 - 4 } & Others & 4 & 4.7 \\
\hline Years of operation & $1-5$ years & 2 & 2.4 \\
\cline { 2 - 4 } & 6-10 years & 11 & 12.9 \\
\cline { 2 - 4 } & 11-20 years & 34 & 40.0 \\
\cline { 2 - 4 } & More than 20 years & 38 & 44.7 \\
\hline Number of employees & 0-75 employees & 35 & 41.2 \\
\cline { 2 - 4 } & $76-200$ employees & 50 & 58.8 \\
\hline Status & Less than RM 5 million & 11 & 12.9 \\
\cline { 2 - 4 } & Less than RM 15 million & 23 & 27.1 \\
\cline { 2 - 4 } & Less than RM 30 million & 12 & 14.1 \\
\cline { 2 - 4 } & Less than RM 50 million & 39 & 45.9 \\
\hline Type of ownership structure & Subsidiary organisation & 35 & 41.2 \\
\cline { 2 - 4 } & Non-subsidiary organisation & 50 & 58.8 \\
\hline Years have certified EMS & Local company & 49 & 57.6 \\
\cline { 2 - 4 } & Foreign company & 18 & 21.2 \\
\cline { 2 - 4 } & Joint venture & 18 & 21.2 \\
\hline & $1-3$ years & 16 & 18.8 \\
\cline { 2 - 4 } & 4-6 years & 50.8 \\
\cline { 2 - 4 } & More than 6 years & 19 & 22.4 \\
\hline
\end{tabular}

\subsection{Hypotheses Testing}

\subsubsection{Simple Regression Analysis}

The simple regression analysis is carried out to examine the relation between GSCM practices and sustainability performance. Table 2 presents a significant positive relationship between GSCM practices and sustainability performance based on the adjusted R-square 0.660 . GSCM practices can justify $66 \%$ of the variation in sustainability performance. Beta coefficient of 0.815 indicates significant positive relation of GSCM towards sustainability performance $(\mathrm{F}=163.809, \mathrm{p}<0.01)$. Thus, the results provide evidence to support $\mathrm{H} 1$ which is consistent with findings from prior research (Younis et al., 2016; Sharma \& Jain, 2017). It was also found in prior studies that GSCM practices positively influence sustainability performance (Kafa, Hani and Mhamedi, 2013).

Table 2. Simple regression on sustainability performance $(\mathrm{N}=85)$

\begin{tabular}{llllll}
\hline Model & B & Std Error & Beta & t. & Sig. \\
\hline Constant & 17.179 & 5.420 & & 3.170 & 0.002 \\
\hline GSCM practices & 0.932 & .073 & 0.815 & 12.799 & 0.000 \\
\hline Model F-statistic & 163.809 & & & & \\
\hline P-value & .000 & .664 & & & \\
\hline R-square & .660 & & & \\
\hline Adjusted R-square & & & & \\
\hline
\end{tabular}




\subsubsection{Multiple Regression Analysis}

Table 3. Multiple regression on sustainability performance $(\mathrm{N}=85)$

\begin{tabular}{llllll}
\hline Model & B & Std Error & Beta & t. & Sig. \\
\hline Constant & 17.703 & 5.177 & & 3.420 & 0.001 \\
\hline Eco-design & 2.012 & 0.324 & 0.502 & 6.213 & 0.000 \\
\hline Green purchasing & 0.260 & 0.431 & 0.062 & 0.602 & 0.549 \\
\hline Environmental cooperation & 1.020 & 0.284 & 0.369 & 3.592 & 0.001 \\
\hline Reverse logistics & 0.115 & 0.403 & 0.021 & 0.284 & 0.777 \\
\hline Model F-statistic & 50.396 & & & & \\
\hline P-value & .000 & & & & \\
\hline R-square & .716 & & & & \\
\hline Adjusted R-square & .702 & &
\end{tabular}

The multiple regression analysis is carried out to examine the relationship between each dimension of GSCM practices and sustainability performance. Based on the table 4.3 above, eco-design practices indicate significant positive influence on sustainability performance $(t=6.213, p=0.0001, b=0.502)$. Thus, H1(a) is supported. It is considered as a strongest contributor to influence sustainability performance that can incorporate environmental awareness as this practice is in the first phase of product lifecycle (Deshmukh \& Vasudevan, 2014). Al Khattab, Abu Rumman and Massad (2015) also highlighted that the main purpose of the product eco-design is to minimise the negative environmental impacts along the production process.

The beta value for environmental cooperation is 0.369 indicating strong contribution to describe sustainability performance $(t=3.592, p=0.001)$. Then, H1 (c) is supported. Younis et al. (2016) acknowledged in their study that the cooperation of all departments in the organisation with regards to the environmental issue must be solid to meet their green objectives and subsequently achieve better performance. It is aligned with the result of the study by Rahim, Fernando and Saad (2016) which is the environmental cooperation among all parties could help GSCM practices to be effectively adopted, and the collaboration with the suppliers will lead the process of GSCM implementation to be easier. Due to that, there is a trend of environmental cooperation as part of the strategic plans in GSCM practices to assure sustainability performance (Sarkis, 2003).

While for the green purchasing and reverse logistics practices, their contribution to sustainability performance is weak with beta coefficients of 0.062 and 0.021 respectively. The link between green purchasing and reverse logistic practices are not significant towards sustainability performance with $\mathrm{p}>0.1$. These results indicate that there is no relation between these two (2) practices with sustainability performance. Hence, results do not provide support for H1(b) and H1(d). However, the results from this study contrast with Nderitu and Ngugi (2014) whereby they found that green purchasing practices provide an immense contribution towards organisational performance. Meanwhile, Rogers and Tibben-Lembke (2001) also provide evidence of the reverse logistic functions to serve GSCM at the optimum level. The summary of findings for the hypotheses are summarised in Table 4 as follows:

Table 4. Summary of findings

\begin{tabular}{lllll}
\hline Hypotheses & Description & Results \\
\hline H1 & $\begin{array}{l}\text { GSCM practices have a positive relationship with sustainability } \\
\text { performance. }\end{array}$ & Supported \\
\hline H1(a) & $\begin{array}{l}\text { Eco-design has a positive relationship with sustainability } \\
\text { performance. }\end{array}$ & Supported \\
\hline H1(b) & Green purchasing has a positive relationship with sustainability & Not supported \\
\hline
\end{tabular}




\begin{tabular}{llll}
\hline \multicolumn{5}{l}{ performance. } \\
\hline H1(c) & $\begin{array}{l}\text { Environmental cooperation has a positive relationship with Supported } \\
\text { sustainability performance. }\end{array}$ \\
\hline H1(d) & $\begin{array}{l}\text { Reverse logistics have a positive relationship with sustainability Not supported } \\
\text { performance. }\end{array}$ \\
\hline
\end{tabular}

\section{Conclusion and Limitation}

This research contributes to both practical and theoretical relevance. Findings from this research suggest that GSCM practices positively influence sustainability performance. However, evidence suggest that not all GSCM dimensions have a significant influence on sustainability performance. Only eco-design and environmental cooperation practices contribute significantly to the sustainability performance of SMEs manufacturing sector in Selangor. Green purchasing and reverse logistics do not influence the firm's sustainability performance. Findings from this research provide significant contributions in the field of green practices in SMEs manufacturing sector. Additionally, research will enhance SMEs awareness to adopt GSCM practices in order to gain a sustainable performance and indirectly minimise environmental issues among the SMEs in this country.

This study also lays as the foundation for future research to extend the research to other sectors such as agriculture, construction and many other sectors for further understanding of GSCM implementations. The green practices might be differently implemented by other sector compared to the manufacturing sector. Thus, it is crucial to gain further insight of GSCM practices in other sectors. This research also highlights the importance of ISO 14001 certification to support GSCM practices and to deal with environmental issues in the effort of enhancing sustainable performance among the Malaysian SMEs. Environmental awareness is essential to strengthen the economic development of this country by improving SME sectors.

Through RBV theory adopted in this study, the utilisation of resources could be tested within the organisations in creating a competitive advantage in their business environment. Sustainability performance could only be realized if organisation gains a competitive advantage. Hence, the ISO 14001 acts as valuable resources to adopt GSCM practices extensively towards achieving sustainable performance. It is believed that ISO 14001 will lead organisations to be more disciplined in practising green practices throughout their business operations. Overall, this study has made both theoretical and practical contributions that might be useful for researchers, practitioners and regulators in Malaysia to strengthen the performance of SMEs manufacturing sector.

However, there are several limitations in this study. First, the sample selection focused on the ISO 14001 SMEs in the manufacturing sector located only in Selangor, one of the states in Malaysia. Hence, the results of this study are restricted to Selangor only and do not fully represent the whole population of the Malaysian manufacturing sectors. Other factors besides ISO 14001 certification which might influence an organisation's decision to utilise GSCM practices should be examined. It is because the certified EMS is considered as an external element while the top management support and the knowledge and skills of the managers are considered as an internal part in the organisations to practise GSCM extensively. However, this study only focused on the role of ISO 14001 certification in the implementation of GSCM practices to achieve sustainable performance.

Besides, the sample size in the data collection is small as the unit analysis of this study is the organisations themselves and focusing only SMEs manufacturing sector located in Selangor. It was time-consuming due to the need to follow up with the respective managers in each of the chosen organisations to complete the questionnaire survey. Additionally, this study did not distinguish between the early and the late adopters of GSCM practices due to the difficulty in obtaining this specific information. Thus, the level of performance could not be measured precisely based on real experience in implementing green practices. It is also a limitation that the performances among organisations are most likely the same regardless of the number of years they have practised GSCM in reality.

\section{Acknowledgements}

Funding for this research was supported by the DUCS grant [File No: 600-UiTMSEL (PI.5/4)(011/2018]. The author would like to extend their appreciation to the Universiti Teknologi MARA (UiTM), particularly research unit of the Universiti Teknologi MARA Selangor for the support in conducting the research and for the publication of the research. 


\section{References}

Al Khattab, S., Abu Rumman, A., \& Massad, M. (2015). The Impact of the Green Supply Chain Management on Environmental-Based Marketing Performance. Journal of Service Science and Management, 8, 588-597. https://doi.org/10.4236/jssm.2015.84059

Alshura, M. S. K., \& Awawdeh, H. Z. Y. (2016). Green Supply Chain Practices as Determinants of Achieving Green Performance of Extractive Industries in Jordan. International Journal of Business and Social Science, 7(7), 166-177.

Amemba, C. S., Nyaboke, P. G., Osoro, A., \& Mburu, N. (2013). Elements of Green Supply Chain Management. European Journal of Business and Management, 5(12), 51-61.

Arimura, T. H., Darnall, N., \& Katayama, H. (2011). Is ISO 14001 a gateway to more advanced voluntary action? The case of green supply chain management. Journal of Environmental Economics and Management, 170-182. https://doi.org/10.1016/j.jeem.2010.11.003

Artha, I. W. B., \& Mulyana, B. (2018). The Effect of Internal and External Factors of Companies on Profitability and its Implications on Stock Price Index of State-Owned Banks. The Economics and Finance Letters, 5(2), 58-71. https://doi.org/10.18488/journal.29.2018.52.58.71

Aruna, J. (2018). Trends in Child Sexual Molestation, Rape and Incest: A View from South West Nigeria. Humanities and Social Sciences Letters, 6(4), 137-148. https://doi.org/10.18488/journal.73.2018.64.137.148

Asif, M., Asghar, F., Younis, A., Mahmood, A., \& Wang, L. Z. (2018). The Role of Social Entrepreneurship in Pakistan and its Impact on Economy. International Journal of Business, Economics and Management, 5(5), 117-127. https://doi.org/10.18488/journal.62.2018.55.117.127

Asli, H. N. (2018). Has Word of Mouth Advertising in Cyberspace Affected Iran's 2017 Presidential Elections?. Humanities and Social Sciences Letters, 6(3), 84-92. https://doi.org/10.18488/journal.73.2018.63.84.92

Audu, T. A. (2018). Effects of Teaching Methods on Basic Science Achievement and Spatial Ability of Basic Nine Boys and Girls in Kogi State, Nigeria. Humanities and Social Sciences Letters, 6(4), 149-155. https://doi.org/10.18488/journal.73.2018.64.149.155

Bachev, H. (2018). Management and Agrarian Sustainability-Impact of Institutions in Bulgaria. International Journal of Management and Sustainability, 7(2), 113-142. https://doi.org/10.18488/journal.11.2018.72.113.142

Balasubramanian, S., \& Shukla, V. (2017). Green supply chain management: an empirical investigation on the construction sector. Supply Chain Management: An International Journal, $22(1)$, 58-81. https://doi.org/10.1108/SCM-07-2016-0227

Chin, T. A., Tat, H. H., \& Sulaiman, Z. (2015). Green Supply Chain Management, Environmental Collaboration and Sustainability Performance. $12^{\text {th }}$ Global Conference on Sustainable Manufacturing, 695-699.

Darnall, N., Jolley, G. J., \& Handfield, R. (2008). Environmental Management Systems and Green Supply Chain Management: Complements for Sustainability. Business Strategy and the Environment, 17(1), 30-45.

Deshmukh, A. \& Vasudevan, H. (2014). Emerging supplier selection criteria in the context of traditional vs. green supply chain management. International Journal of Managing Value and Supply Chains (IJMVSC), 5(1), 19-33.

Dubey, R., Bag, S., \& Ali, S. S. (2014). Green supply chain practices and its impact on organisational performance: An insight from Indian rubber industry. International Journal Logistics Systems and Management, 19(1), $20-42$.

Hassan, M. G., Ashari, H., \& Nordin, N. (2016). Environmental Stewardship Issue Among Malaysian Manufacturing Firms. International Journal Supply Chain Management, 5(2), 36-42.

Kassim, Z. A., \& Sulaiman, M. (2011). Market orientation and leadership styles of managers in Malaysia. International Journal of Leadership Studies, 6(2).

Kim, M., \& Chai, S. (2017). Implementing Environmental Practices for Accomplishing Sustainable Green Supply Chain Management. Journal of Sustainability, 9, 1-17. https://doi.org/10.3390/su9071192

Lee, K., \& Cheong, M. (2011). Measuring a carbon footprint and environmental practice: the case of Hyundai Motors Company. Industrial Management \& Data Systems, 111(6), 961-978.

Madhani, P. M. (2010). Resource Based View (RBV) of Competitive Advantage. Retrieved 15 August 2018 , from https://papers.ssrn.com/sol3/papers 
Mentzer, J. T. (2001). Supply chain management. United States of America: Sage Publications, Inc.

Mogeni, L. M., \& Kiarie, D. M. (2016). Effect of Green Logistics Practices on Performance of Supply Chain in Multinational Organizations in Kenya.

Muma, B., Nyaoga, R., Matwere, R., \& Nyambega, E. (2014). Green supply chain management and environmental performance among tea processing firms in Kericho County- Kenya. International Journal of Economics, Finance and Management Sciences, 2(5), 270-276. https://doi.org/10.11648/j.ijefm.20140205.11

Nderitu, M., \& Ngugi, K. (2014). Effects of green procurement practices on an organization performance in manufacturing industry: case study of East African Breweries Limited. European Journal of Business Management, 2(1), 341-352.

Nee, G. Y., \& Wahid, N. A. (2010). The Effect of ISO 14001 Environmental Management System Implementation on SMEs Performance: An Empirical Study in Malaysia. Journal of Sustainable Development, 3(2), 215-220.

Neramballi, A., Sequeira, M., Rydell, M., Vestin, A. \& Ibarra, M. (2017). A Comprehensive organizational performance: A review. Asia Pacific Journal of Research, 1,104-109.

Paulraj, A. (2011). Understanding the Relationships between Internal Resources and Capabilities, Sustainable Supply Management and Organizational Sustainability. Journal of Supply Chain Management, 47, 19-37.

Rahim, S. A., Fernando, Y., \& Saad, R. (2016). Sustainable Green Supply Chain Management and Impact on Organizations. Journal of Emerging Trends in Economics and Management Sciences, 7(3), 147-155.

Rao, P., \& Holt, D. (2005). Do green supply chains lead to competitiveness and economic performance?. International Journal of Operations and Production Management, 25(9), 898-916.

Rogers, D. S., \& Tibben-Lembke, R. (2001). An examination of reverse logistics practices. Journal of Business Logistics, 22(2), 129-48. https://doi.org/10.1002/j.2158-1592.2001.tb00007.x

Sarkis, J. (2003). A Strategic Decision Framework for Green Supply Chain Management. Journal of Cleaner Production, 11, 397-409. https://doi.org/10.1016/S0959-6526(02)00062-8

Schaper, M. (2002). The challenge of environmental responsibility and sustainable development: Implications for SME and entrepreneurship academics. Radical Changes in the World: Will SMEs Soar or Crash, pp. 541-53.

The Star Online. (2017). SMEs growth outspaces country's GDP growth. Retrieved 17 April 2018, from https://www.thestar.com.my/busines

Vijayvargy, L. (2017). Empirical Study on Adoption of Green Supply Chain Practices for Developing Economy. Proceedings of the International Multi-Conference of Engineers and Computer Scientists 2017, 2.

Wooi, G. C., \& Zailani, S. (2010). Green Supply Chain Initiatives: Investigation on the Barriers in the Context of SMEs in Malaysia. International Business Management, 4(1), 20-27. https://doi.org/10.3923/ibm.2010.20.27

Yacob, P., Aziz, N. S., Makmor, M. F. M., \& Zin, A. W. M. (2013). The Policies and Green Practices of Malaysian SMEs. Global Business and Economics Research Journal, 2(2), 52-74.

Younis, H., Sundarakani, B., \& Vel, P. (2016). The impact of implementing green supply chain management practices on corporate performance. Competitiveness Review, 26(3). https://doi.org/10.1108/CR-04-2015-0024

Zhu, Q., Sarkis, J., \& Lai, K. (2007). Initiatives and outcomes of green supply chain management implementation by Chinese manufacturers. Journal of Environmental Management, 85(1), 179-189.

Zhu, Q., Sarkis, J., Cordeiro, J., \& Lai, K. (2008). Firm-level correlates of emergent green supply chain management practices in the Chinese context. Omega, 36(4), 577-591. https://doi.org/10.1016/j.omega.2006.11.009

Zsidisin, G., \& Siferd, S. (2001). Environmental purchasing: a framework for theory development. European Journal of Purchasing \& Supplying Management, 7, 1-73. https://doi.org/10.1016/S0969-7012(00)00007-1

Zsidisin, G. A., \& Hendrick, T. E. (1998). Purchasing's involvement in environmental issues: a multi-country perspective. Industrial Management \& Data Systems, 98(7), 313-320. https://doi.org/10.1108/02635579810241773 